FOLIA POMERANAE UNIVERSITATIS TECHNOLOGIAE STETINENSIS

Folia Pomer. Univ. Technol. Stetin., Oeconomica 2017, 335(87)2, 113-122

Marcin KLINOWSKI

\title{
METODYKA PROWADZENIA ZAJĘĆ Z RACHUNKOWOŚCI PODATKOWEJ NA UCZELNIACH EKONOMICZNYCH
}

\author{
THE METHODOLOGY OF TAX ACCOUNTING TEACHING \\ ON ECONOMIC STUDIES
}

Katedra Rachunku Kosztów, Rachunkowości Zarządczej i Controllingu, Uniwersytet Ekonomiczny we Wrocławiu, ul. Komandorska 118/120, 54-345 Wrocław, marcin.klinowski@ue.wroc.pl

\begin{abstract}
Summary. There are many ways to transfer knowledge to students. Constantly sought and developed are the methods and techniques of education that will enable effective knowledge and skills transfer. The aim of this study is to examine what methods of teaching tax accounting are the most appreciated by the students. Presented considerations are based on the empirical studies carried out among students on economy faculty.
\end{abstract}

Słowa kluczowe: podatki, rachunkowość podatkowa, metodyka zajęć.

Key words: taxes, tax accounting, methodology of lessons.

\section{WSTĘP}

Dydaktyka, oprócz badań naukowych, stanowi obecnie sens istnienia każdej polskiej uczelni ekonomicznej; według Okonia (2007) „[...] jest nauką o kształceniu i samokształceniu, ich celach i treści oraz metodach, środkach i organizacji” (s. 55). To, co łączy nauczanie i uczenie się, to zarówno cel, jak i stosowane w procesie kształcenia metody, formy organizacyjne i środki dydaktyczne (Bereźnicki 2011). Dyskutowanie o dydaktyce ogólne wydaje się jednak obecnie niewystarczające. Wynika to z pewnej specyfiki poszczególnych obszarów nauczania; można wyróżnić dydaktykę ogólną oraz szczegółową (Kupisiewicz 2005). Niektórzy autorzy proponują nawet jeszcze bardziej precyzyjny podział na następujące obszary dydaktyki: ogólny, szczegółowy, określonego typu szkolnictwa, środowiskowy i specjalistyczny (Półturzycki 2014). Zasadne jest zatem badanie procesu dydaktycznego indywidualnie dla każdego przedmiotu, gdyż cechować go może odmienne od innych podejście, np. o charakterze specjalistycznym.

Jednym z podstawowych zadań dydaktyki jest analiza składników systemu dydaktycznego. Służy to przede wszystkim formułowaniu norm, reguł, wykrywaniu nieprawidłowości procesu kształcenia (Bereźnicki 1994) oraz doskonaleniu metod nauczania. Istnieje wiele sposobów przekazywania wiedzy studentom. Stale poszukiwane i udoskonalane są metody i techniki nauczania, które umożliwią efektywne zdobywanie wiedzy, doskonalenie umiejętności oraz kompetencji społecznych. Wiążą są one nieodzownie z aktywizacją słuchaczy, którzy poprzez aktywny udział w zajęciach mogą efektywnie przyswajać przewidziany dla danego przedmiotu zakres materiału. Tymczasem aktywność studentów w dużym stopniu uzależniona jest od 
tego, czy proponowane formy prowadzenia zajęć są dla nich atrakcyjne. Warto zatem stale badać, jakie są dydaktyczne preferencje studentów dotyczące poszczególnych przedmiotów, aby systematycznie doskonalić proces dydaktyczny.

Celem niniejszego opracowania jest zbadanie, jakie metody nauczania w odczuciach studentów uczelni ekonomicznej są najlepsze w przypadku przedmiotu rachunkowość podatkowa oraz co stanowi największą przeszkodę w procesie dydaktycznym.

\section{MATERIAŁ I METODY}

Rozważania na temat metod nauczania rachunkowości podatkowej na studiach ekonomicznych bazują na badaniu ankietowym. Badanie to przeprowadzone zostało w grupie studentów stacjonarnych ostatniego roku studiów II stopnia na kierunku finanse i rachunkowość (FIR) na Wydziale Zarządzania, Informatyki i Finansów Uniwersytetu Ekonomicznego we Wrocławiu w roku akademickim 2016/2017. Przyjęto, że studenci ostatniego roku studiów udzielą najbardziej użytecznych odpowiedzi. Powinno to być wynikiem potencjalnie większego, w stosunku do młodszych roczników, doświadczenia zawodowego oraz zaliczenia większej liczby przedmiotów podatkowych.

Przedmiot rachunkowość podatkowa prowadzony jest dla studentów wszystkich specjalności na kierunku finanse i rachunkowość. Oznacza to, że dla niektórych badanych studentów są to pierwsze zajęcia z podatków, podczas gdy dla pozostałych jest to kontynuacja edukacji w tym zakresie. Kurs ten prowadzony jest na studiach stacjonarnych w formie wykładu oraz ćwiczeń w wymiarze 15-godzinnym dla każdej z form. Podstawą zaliczenia wykładu jest test wyboru; w przypadku ćwiczeń są to zadania do rozwiązania.

\section{WYNIKI I DYSKUSJA}

W ankiecie zadano studentom 10 pytań dotyczących pożądanych form zajęć z rachunkowości podatkowej, metod procesu dydaktycznego oraz przeszkód utrudniających przyswojenie wiedzy z analizowanego przedmiotu. Większość pytań miało charakter pytań zamkniętych; 3 dawały możliwość podania indywidualnej odpowiedzi. Ankiety wypełniło 155 osób spośród 187 wszystkich studentów na kierunku (co stanowi niemal 83\%), co pozwala stwierdzić, że uzyskane wyniki są reprezentatywne.

Wśród badanych studentów zdecydowaną większość stanowiły kobiety - prawie 3/4 studentów na kierunku finansów i rachunkowości. Struktura ta nie zmienia się od kilku lat na kierunku, który zdominowany jest przez kobiety.

W cyklu 2015-2017 na studiach II stopnia na badanym kierunku uruchomione zostały 4 specjalności; strukturę prezentuje ryc. 1.

Spośród ankietowanych najwięcej osób wybrało specjalność audyt finansowy i podatkowy (41\%). Na drugim miejscu, ze względu na popularność, uplasowały się rachunkowość zarządcza i controlling (35\%). Nieco mniej ankietowanych studentów (15\%) wybrało rynek nieruchomości. Najmniej osób wybrało analitykę finansową i zarządzanie ryzykiem (10\%). Zainteresowania studentów, wynikające z wyboru specjalności, mogą mieć istotny wpływ na preferencje dotyczące oczekiwań i sposobów prowadzenia zajęć z rachunkowości podatkowej; przedstawiono to badanie szczegółowo w dalszej części niniejszego opracowania. 


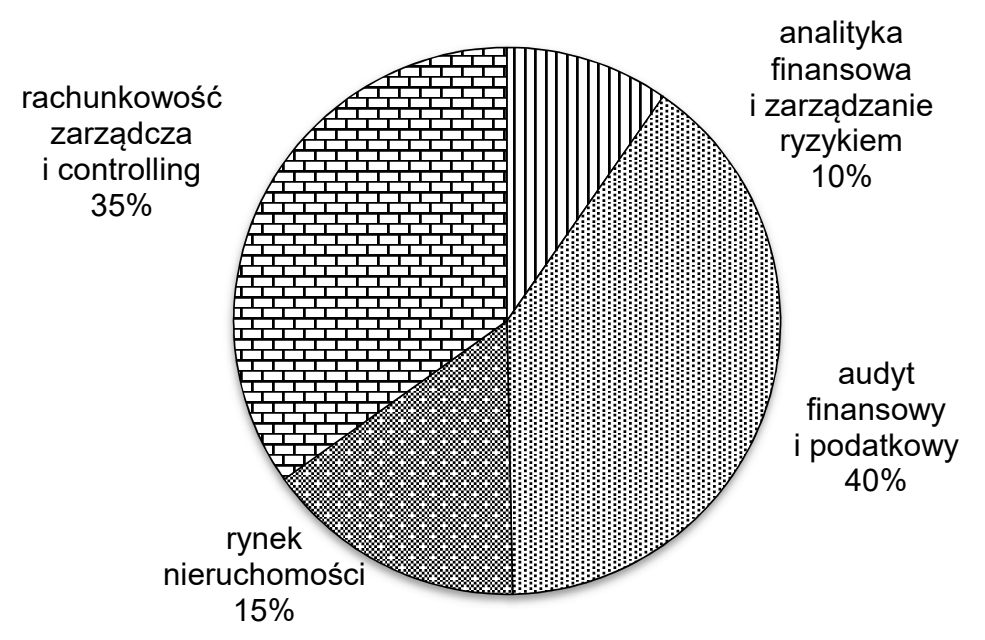

Rys. 1. Specjalności na kierunku finanse i rachunkowość

To, w jaki sposób wg studentów ma być przekazywana wiedza z rachunkowości podatkowej, uzależnione może być w dużym stopniu od posiadanego doświadczenia zawodowego, w szczególności, jeśli doświadczenie to jest tożsame lub zbliżone do wybranego kierunku. Okazało się, że większość ankietowanych studentów (81\%) posiada już doświadczenie zgodne z kierunkiem finanse i rachunkowość. Ponadto ponad połowa deklaruje, że zdobyła je podczas zatrudnienia na podstawie umowy cywilnoprawej (40\%) lub umowy o pracę $(17 \%)$. Pozostali (23\%) zdobywali doświadczenie zawodowe zgodne z kierunkiem w formie stażu lub pomocy w swoim rodzinnym przedsiębiorstwie. Największy udział umów cywilnoprawnych w tym zestawieniu wynika przede wszystkim z preferencji ubezpieczeniowych zarówno w przypadku studentów, jak i ich zleceniodawców.

Kontynuując wątek doświadczenia zawodowego, zadano badanym pytanie, czy jest ono związane bezpośrednio z rachunkowością podatkową. Zdecydowana większość ankietowanych (68\%) nie posiada, niestety, doświadczenia zawodowego połączonego z podatkami; ma to znaczny wpływ na oczekiwania wobec prowadzenia zajęć z rachunkowości podatkowej. Są one pochodną przede wszystkim świadomości studentów o konieczności posiadania wiedzy z tego zakresu zarówno w odniesieniu do przedsiębiorstw, jak i indywidualnych rozliczeń podatkowych. Prawie 1/3 ankietowanych (32\%) posiada natomiast, w różnym zakresie, doświadczenie zawodowe związane z rachunkowością podatkową. Oczekiwania tych studentów wobec rachunkowości podatkowej są niewątpliwie znacznie większe niż pozostałych. Zależność ta jest oczywista i nie wzbudza wątpliwości. Jeśli chodzi o sposób prowadzenia zajęć, stanowić może ona jednak pewną przeszkodę. Trudniej jest bowiem wówczas zoptymalizować metody dydaktyczne w celu sprostania oczekiwaniom studentów.

Kolejne pytanie ankiety dotyczyło preferowanej struktury zajęć z rachunkowości podatkowej; podane odpowiedzi przedstawia ryc. 2. Ponad połowa (52\%) ankietowanych uznała, że najlepszym połączniem jest wykład z ćwiczeniami. Jednoczenie $39 \%$ badanych studentów uważa, że połączenie tych form należy uzupełnić dodatkowo o zajęcia laboratoryjne. Natomiast 9\% wybrało połącznie wykładu z laboratoriami za najlepsze rozwiązanie. Co ciekawe, nikt nie zaznaczył odpowiedzi, która wskazuje wykład jako jedyną formę prowadzenia zajęć. Prawie wszyscy (91\%) oczekują zatem mieszanej formy przekazywania wiedzy z zakresu podatków i ubezpieczeń. 


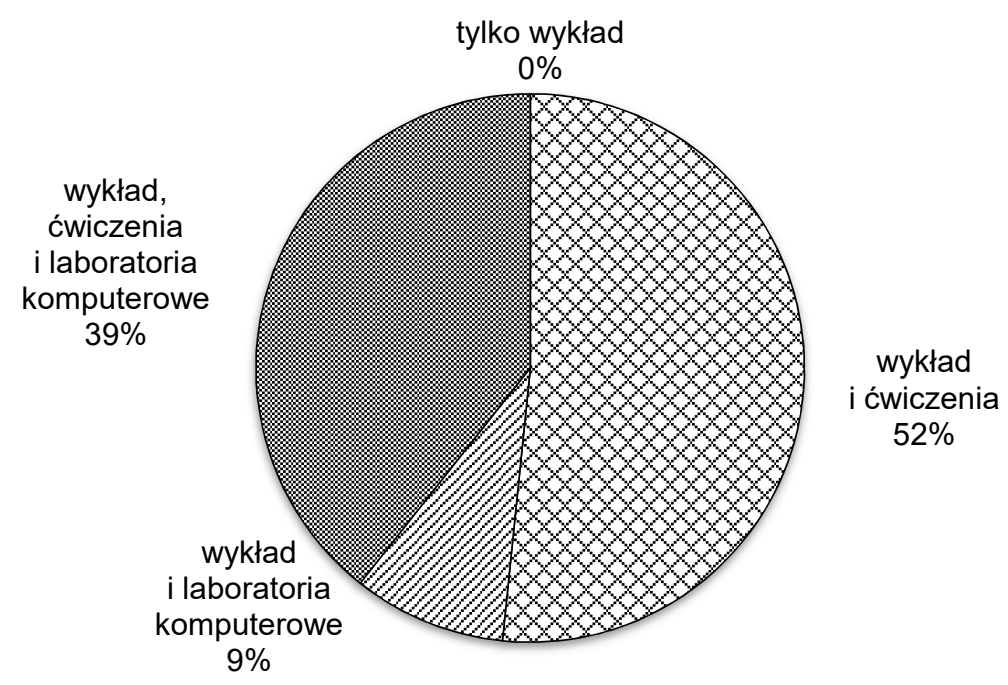

Ryc. 2. Preferowana przez studentów struktura zajęć z rachunkowości podatkowej

Warto zauważyć też, że studenci z dwóch specjalności, tj. z audytu finansowego i podatkowego oraz z rachunkowości zarządczej i controllingu, częściej, niż pozostali, wybierali wariant składający się ze wszystkich wymienionych form zajęć. Związane jest to niewątpliwie z dużym zainteresowaniem studentów przedmiotami podatkowymi, które są zbieżne z wybranymi specjalnościami. Laboratoria umożliwiają przy tym zapoznanie się z programami komputerowymi, które wykorzystane mogą być w pracy zawodowej do rozliczeń podatkowo-ubezpieczeniowych. Odpowiedzi w znikomym tylko stopniu zależne były od doświadczenia zawodowego, chociaż osoby deklarujące doświadczenie związane z rachunkowością podatkową również częściej wybierały najbardziej złożony wariant zajęć. Wyniki nie zależały natomiast w ogóle od płci.

W dalszej części ankiety zadano pytanie o preferowane formy pracy dotyczące wykładów z rachunkowości podatkowej; wskazane odpowiedzi podano na ryc. 3.

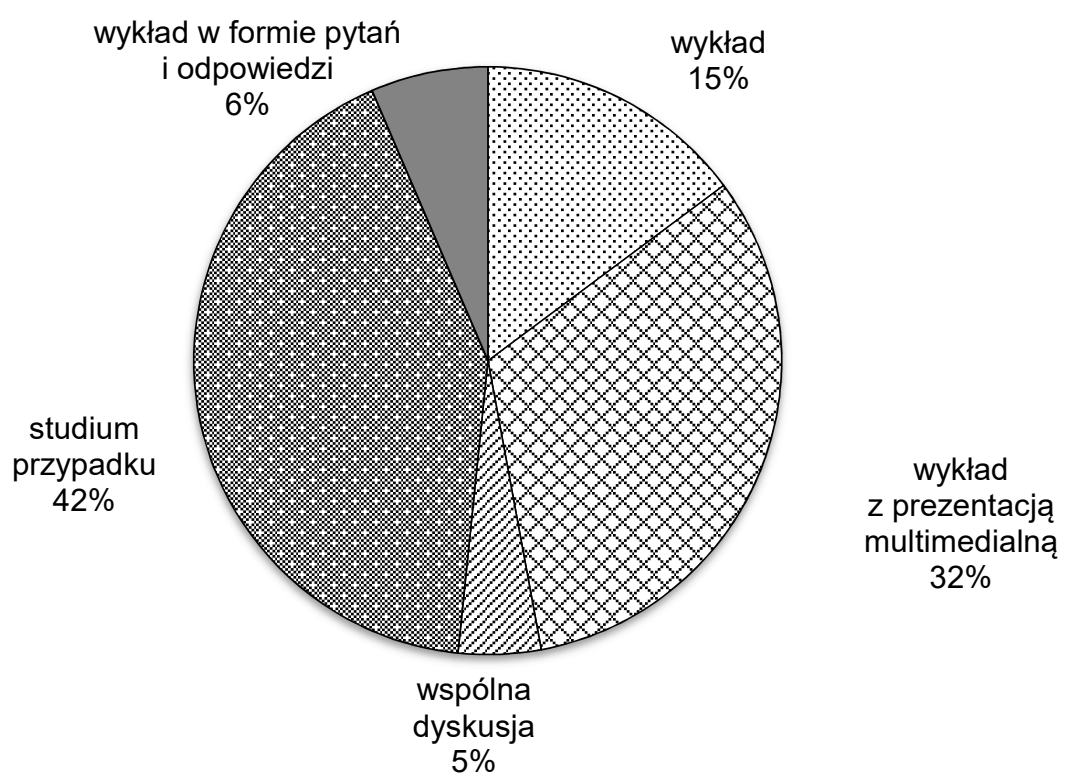

Ryc. 3. Preferowane przez studentów formy prowadzenia wykładów z rachunkowości podatkowej 
Najwięcej ankietowanych (42\%) wskazało na studium przypadku jako najlepszą formę prowadzenia wykładu. Nieco mniej (32\%) badanych studentów uznało, że połącznie wykładu z prezentacją multimedialną jest optymalną formą dydaktyczną; ponadto $15 \%$ wybrało sam wykład. Tym samym klasyczna forma prowadzenia wykładu wydaje się najbardziej popularna wśród studentów - niemal połowa odpowiedzi (47\%). Ankietowani oczekują jednocześnie od prowadzących korzystania z multimedialnych technik wizualizacji. Ponadto wśród odpowiedzi pojawiły się jeszcze w niemal identycznej ilości wskazania na wykład w formie pytań i odpowiedzi $(6 \%)$ oraz wspólną dyskusję (5\%); nikt nie zaproponował innych form prowadzenia wykładu.

Warto też zauważyć, że ani doświadczenie zawodowe, ani płeć nie wpływa znacznie na preferowaną strukturę zajęć. Przyznać jednak należy, że kobiety nieco chętniej, niż mężczyźni, wskazywali na wykład z prezentacją, zamiast samego wykładu. Natomiast osoby z doświadczeniem zbieżnym z rachunkowością podatkową nie wybierały tak często wykładu z prezentacją na rzecz samego wykładu. Odpowiedzi korelowały za to dość mocno ze specjalnościami. Grupy związane z finansami (analityka finansowa i zarządzanie ryzykiem oraz rynek nieruchomości) chętniej wybierały klasyczne metody w postaci wykładu, który ewentualnie wzbogacony był prezentacją multimedialną. Natomiast studenci ze specjalności bardziej związanych z rachunkowością (audyt finansowy i podatkowy oraz rachunkowość zarządcza i controlling) zdecydowanie częściej wskazywali na studium przypadku jako najlepszą formę prowadzenia wykładu.

Zdecydowanie większą zgodność odpowiedzi odnotowano w przypadku pytania o preferowane formy pracy w ramach ćwiczeń (ryc. 4).

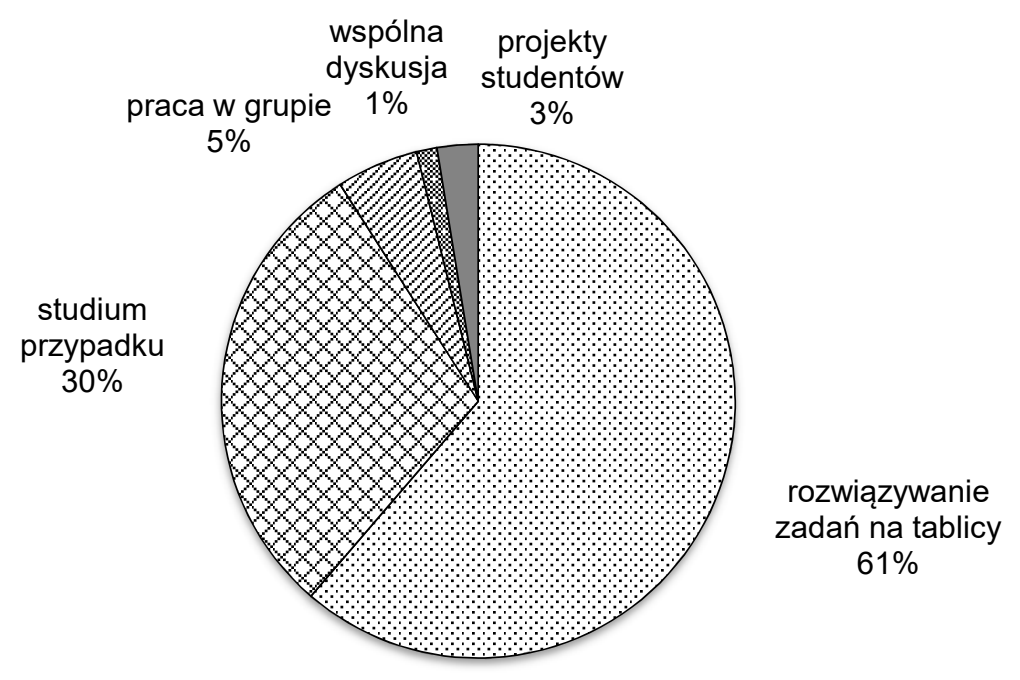

Ryc. 4. Preferowane przez studentów formy prowadzenia ćwiczeń z rachunkowości podatkowej

Większość studentów (61\%) uznała rozwiązywanie zadań na tablicy za najlepszy sposób prowadzenia ćwiczeń z rachunkowości podatkowej, prawie 1/3 natomiast wskazała na studium przypadku, podobnie jak w przypadku wykładów; jest to zatem interesująca forma według studentów. Pozostałe odpowiedzi cieszyły się zdecydowanie mniejszym zainteresowaniem. Pracę w grupie wybrało tylko 5\%, pracę w formie realizacji własnych projektów - 3\%, natomiast wspólną dyskusję - 1\%. Nikt nie wskazał na prezentacje wykonywane przez studentów oraz nikt nie podał innych (niewymienionych) form prowadzenia ćwiczeń. 
Ponadto warto zauważyć, że ani płeć, ani doświadczenie zawodowe nie miały prawie żadnego wpływu na udzielane odpowiedzi. Tym niemniej studenci ze specjalności analityka finansowa i zarządzanie ryzykiem jeszcze częściej, niż na studium przypadku, wskazywali na rozwiązywanie zadań na tablicy.

W ankiecie zapytano również studentów o właściwe ich zdaniem składowe weryfikacji wiedzy i umiejętności z rachunkowości podatkowej; wyniki obrazuje ryc. 5.

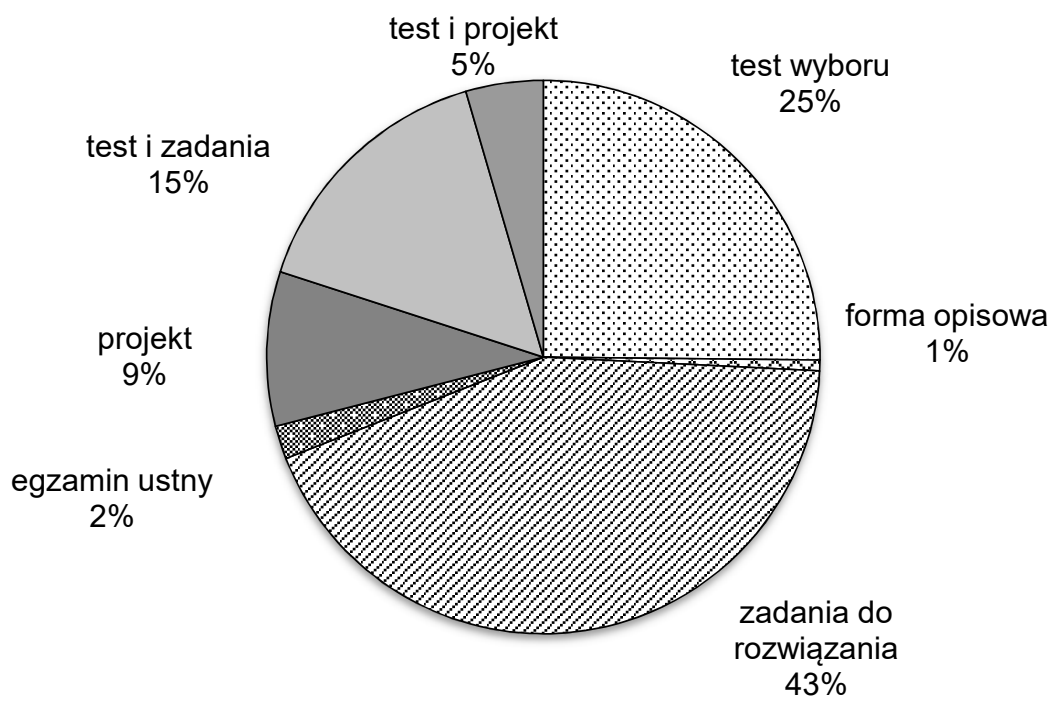

Ryc. 5. Elementy, które według studentów najlepiej weryfikują wiedzę i umiejętności z rachunkowości podatkowej

Najwięcej zwolenników zyskały zadania do rozwiązania (43\%), 1/4 ankietowanych uważa, że najlepszą formą weryfikacji jest natomiast test, $20 \%$ studentów wybrało mieszaną formę sprawdzania poziomu wiedzy z zakresu podatków - wskazywano test i zadania (15\%) oraz test i projekt $(5 \%)$. Samodzielny projekt wybrało natomiast $9 \%$ ankietowanych. Bardzo mało odpowiedzi dotyczyło egzaminowania ustnego (2\%) oraz formy opisowej (1\%).

Podobnie jak w przypadku poprzedniego pytania, płeć nie miała prawie żadnego wpływu na podane odpowiedzi. Jednak osoby $z$ doświadczeniem zawodowym w zakresie podatków o wiele rzadziej wskazywały na test niż na zadania oraz formy mieszane w postaci testu i zadań. Ponadto studenci ze specjalności analityka finansowa i zarządzanie ryzykiem częściej, niż pozostali, wybierali formę testu i zadań, a studenci ze specjalność audyt finansowy i podatkowy chętniej wskazywali same zadania.

Następne pytanie dotyczyło opinii studentów nt. przydatności rachunkowości podatkowej w życiu zawodowym. Im większa bowiem ona jest, tym ankietowanym bardziej zależeć powinno na zdobyciu wiedzy i umiejętności w tym zakresie. Niemal wszyscy uznali zajęcia $z$ rachunkowości podatkowej za przydatne w swoim życiu zawodowym, co obrazuje ryc. 6 .

Aż $67 \%$ studentów wskazało, że zajęcia z zakresu podatków są zdecydowanie, a 32\%, że są raczej przydatne w pracy. Tylko $2 \%$ ankietowanych odpowiedziało, że zajęcia z rachunkowości podatkowej nie będą im potrzebne w pracy zawodowej.

Ostatnie pytanie związane było z przeszkodami, które utrudniły studentom naukę rachunkowości podatkowej (ryc. 7). 


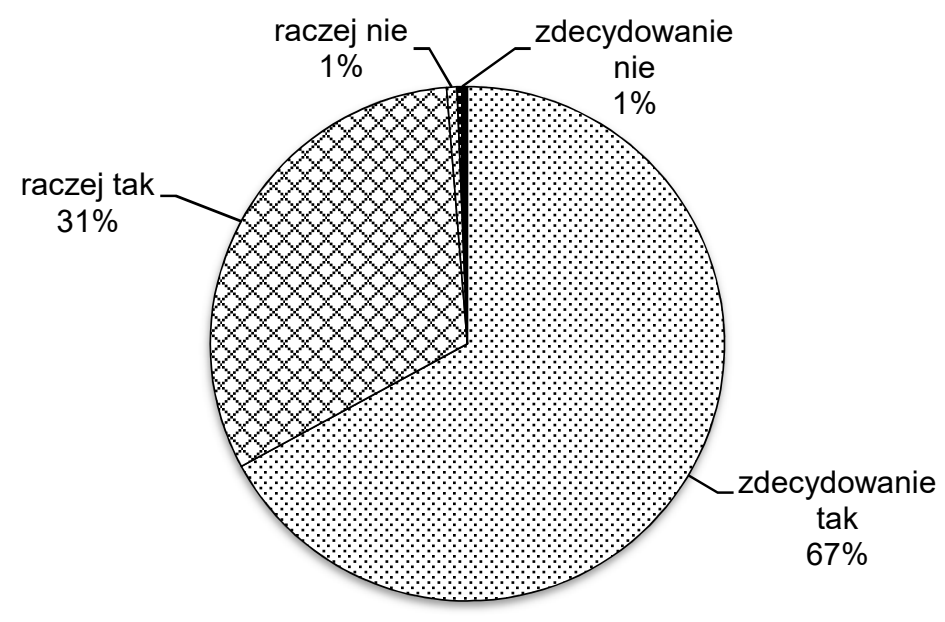

Ryc. 6. Czy zajęcia z rachunkowości podatkowej są przydatne w życiu zawodowym?

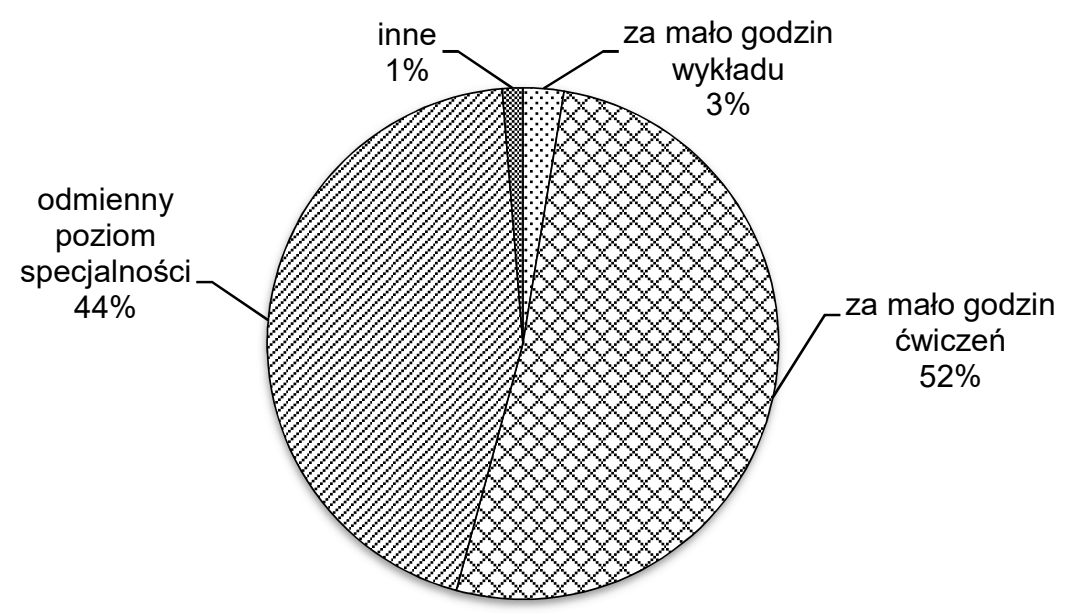

Ryc. 7. Co najbardziej utrudnia naukę rachunkowości podatkowej?

Ponad połowa (52\%) studentów odpowiedziała, że przyswojenie materiału z zakresu podatków najbardziej utrudniła im zbyt mała liczba godzin ćwiczeń. Porównywalnie dużo odpowiedzi (45\%) wskazywało na odmienny poziom wiedzy podatkowej na różnych specjalnościach - to dwie główne przyczyny wskazane przez studentów. Niewielu (ponad 2\%) ankietowanych wskazało na zbyt małą liczbę godzin wykładów; nieliczne odpowiedzi dotyczyły indywidualnych trudności, takich jak zawiłość polskiego prawa podatkowego.

Płeć nie miała prawie żadnego wpływu na udzielane odpowiedzi. Za to osoby z doświadczeniem zbieżnym z rachunkowością podatkową dwa razy częściej wskazywały na zbyt małą liczbę godzin ćwiczeń aniżeli na odmienny poziom wiedzy podatkowej na różnych specjalnościach. Podobnie odpowiedzi rozkładały się w grupie studentów związanych z rachunkowością (audyt finansowy i podatkowy oraz rachunkowość zarządcza i controlling). Natomiast studenci ze specjalności finansowych (analityka finansowa i zarządzanie ryzykiem oraz rynek nieruchomości) za największą trudność uznali odmienny poziom wiedzy podatkowej na różnych specjalnościach (64\%); oznacza to dość poważną przeszkodę w osiągnięciu celu dydaktycznego dla prowadzących. 


\section{PODSUMOWANIE}

W niniejszym opracowaniu zbadano przede wszystkim, jakie metody nauczania w odczuciach studentów uczelni ekonomicznej są najlepsze w nauczaniu w ramach przedmiotu rachunkowość podatkowa oraz co stanowi przeszkodę w procesie dydaktycznym dotyczącym tego przedmiotu dla studentów wybranego kierunku na Uniwersytecie Ekonomicznym we Wrocławiu.

Na podstawie przeprowadzonych badań ankietowych można jednoznacznie stwierdzić, że niemal wszyscy studenci analizowanego kierunku uważają przedmiot z rachunkowości podatkowej za bardzo przydatny w ich życiu zawodowym. Tym samym oczekują od prowadzących stosowania odpowiednich metod dydaktycznych, które umożliwią im zrozumienie mechanizmów naliczania i rozliczania podatków oraz ubezpieczeń.

Podsumowując przeprowadzone badanie, można ponadto stwierdzić, że:

1. Zdaniem studentów najlepszą formą zajęć z rachunkowości podatkowej jest kombinacja wykładu i ćwiczeń lub wykładu, ćwiczeń oraz laboratoriów. Zainteresowanie zajęciami komputerowymi jest zauważalnie większe w przypadku studentów specjalności, które są w pewien sposób zbieżne z podatkami; być może warto zastosować odmienną, od obecnej, strukturę zajęć, w zależności od specjalności.

2. W przypadku wykładów studenci w większości preferują studium przypadku oraz klasyczne przekazywanie wiedzy w formie prezentacji. Jednocześnie oczekują od wykładowcy korzystania z multimedialnych technik wizualizacji. Jest to naturalna konsekwencja zmieniających się standardów prezentacji oraz pewnej wygody słuchaczy.

3. W przypadku ćwiczeń ankietowani wskazali rozwiązywanie zadań na tablicy oraz studium przypadku jako preferowane formy pracy. Studium przypadku było również wskazywane w odpowiedziach dotyczących preferowanych metod dydaktycznych dotyczących wykładów. Należałoby zatem częściej, niż obecnie, stosować tę metodę, skoro jest ona atrakcyjna dla studentów.

4. Ważnym elementem weryfikacji wiadomości z rachunkowości podatkowej powinny być praktyczne zadania do rozwiązania. Studenci uznali, że umiejętności z zakresu rozliczeń podatkowo-ubezpieczeniowych są dla nich najważniejsze i powinny stanowić istotę zaliczenia przedmiotu.

5. Naukę rachunkowości podatkowej najbardziej utrudniają mała, zdaniem studentów, liczba godzin ćwiczeń oraz odmienny poziom wiedzy na poszczególnych specjalnościach. Należałoby zatem rozważyć zwiększenie godzin ćwiczeń oraz przesunięcie kursu na wcześniejsze semestry lub nawet na studiach niższego stopnia, aby wyeliminować różnice programowe w zakresie podatków.

\section{WNIOSKI}

Zaprezentowane wyniki badań ankietowych mogą być pomocne w tworzeniu struktury oraz zakresu przedmiotu rachunkowość podatkowa na specjalnościach kierunków ekonomicznych. Mogą też być wykorzystane przez prowadzących do doboru odpowiednich metod dydaktycznych. Warto zauważyć, że ciągłe doskonalenie procesu dydaktycznego decyduje o przydatności i atrakcyjności oferty kształcenia studentów. Dlatego uczelnie wyższe powinny stale monitorować oczekiwania studentów oraz ich potencjalnych pracodawców wobec oferowanych przedmiotów. Tylko takie podejście bowiem gwarantuje zaspokojenie potrzeb stale zmieniającego się rynku. 


\section{PIŚMIENNICTWO}

Bereźnicki F. 1994. Dydaktyka ogólna w zarysie. Koszalin, Miscellanea, 13.

Bereźnicki F. 2011. Podstawy kształcenia ogólnego. Kraków,Impuls, 9.

Kupisiewicz C. 2005. Podstawy dydaktyki. Warszawa, WSiP, 14.

Okoń W. 2007. Nowy słownik pedagogiczny. Warszawa, Żak Wydaw. Akad., 55.

Półturzycki J. 2014. Dydaktyka dla nauczycieli. Toruń, Wydaw. Adam Marszałek, 24-25. 
